\title{
The Development of Character Education Model Based on School Culture
}

\author{
Hardianto Rahman ${ }^{1 *}$ Jamaluddin $^{1}$, Umar $^{1}$ \\ ${ }^{1}$ Islamic Institute of Muhammadiyah Sinjai, Sinjai 92611, Indonesia \\ *Corresponding author. Email: antoks.hr@gmail.com
}

\begin{abstract}
The objectives of this study are: (1) to obtain empirical data about the implementation of character education in Sinjai, (2) to produce a valid and practical School-based character education model. (3) produce effective School-based character education models. This study was designed using the ADDIE model (Analysis, Design, Development, Implementation, Evaluation). To get a valid, practical and effective model, instruments and model devices were developed. The products produced are model books, teacher manuals and guidebooks for students. The research results are: (1) the results of the preliminary study at the analysis stage revealed that the implementation of character education has not been carried out comprehensively, the fulfilment of the environmental situation and school culture supporting the implementation of character education has not been fulfilled as a whole and the character of students is generally low, (2) culture-based character education models the school fulfil the validity criteria, and practicality. Declared valid based on the results of the validity test by experts and practical based on the results of the teacher's response to the application of the model in the category of "very good". The results of the implementation of the model are categorized as "very good", (3) the model of school culture-based character education meets the effectiveness criteria because it gets a positive response from students and can improve the character of students.
\end{abstract}

Keywords: education, school culture, character

\section{INTRODUCTION}

So far, only schools (institutions) outside the family or informal school which still have the willing to make changes, either individuals or groups [1]. The results of education in schools also make people have a system and a material value scheme based on their level of education [1]. In 2003, the regulation of national education system (SISDIKNAS) states that among the goals of national education is to develop the potential of students to have intelligence, personality and good character. Therefore, education in schools has a very important role in shaping the attitudes, behaviour and character of students.

The research results of Bennet [2], revealed that what was recorded in the memory of students in school, turned out to have a very large influence on their personality when they grow up. Thus, school is one effective vehicle for character internalization of students. In character education in schools, all components (stakeholders) must be involved, including the components of education itself, namely curriculum content, learning and assessment processes, quality of relationships, handling or management of subjects, school management, implementation of cocurricular activities or activities, empowerment of infrastructure, financing, and work ethic for all residents and the school environment. Cultivating character education is an early way of preparing students to anticipate changes in the life order that begin to lead to moral decadence. The process is emphasized as a culture, so that students are able to make character education a way of thinking, behaving, and behaving in schools and communities [3].

Study results from Martin Berkowitz from the University of Missouri-St. Louis, showed an increase in motivation of school students in achieving academic achievement in schools that implement character education [4]. Classes that are comprehensively involved in character education show a drastic decline in students' negative behaviour which can hinder their academic success. However, according to Ma'mur the character of the young generation is already at a very worrying point, the moral of this nation has been separated from the norms, ethics, religion, and noble culture of the nation [5].

The poor practice of education in schools indicates that there is no conducive school culture that creates fraudulent or dishonest behaviour among teachers and students. Likewise, the condition of school culture that does not support the creation of honesty character. According to Baedowi "the teachers have lost the spirit and values of honesty in the practice of education" [1]. This statement is the impact of the symptoms of fraud that are evenly distributed in the national examinations conducted by education actors in schools. Saefullah [6], even calling schools in Indonesia failed to build national character.

According to Lickona, a nation is heading for destruction, if it has ten signs such as; (1) increasing violence among adolescents; (2) culturing dishonesty; (3) fanatical attitude towards groups (peer group); (4) low respect for parents and teachers; (5) increasingly blurred moral good and bad; (6) worsening use of language; (7) increased self-destructive behaviours such as drug use, alcohol and free sex; (8) lack of sense of responsibility as individuals and as citizens; (9) 
the decline in work ethic, and (10) the existence of mutual suspicion and lack of concern among others [7].

Thus, the implementation of educational reforms that are more focused on developing the character of students is very important according to the mandate of the Law in order to create quality human resources of high quality and integrity. especially through the introduction of the concept of holistic education. Therefore, a successful education system is one that can shape human beings based on local culture that is indispensable in realizing a respectable national state.

In accordance with the Master Design Character education designed by the Ministry of National Education strategies for developing character education can be carried out through the transformation of school culture and habituation through self-development activities (extracurricular) [8]. This is in line with Berkowitz's thinking, cited by Elkind and Sweet which states that the implementation of character education through cultural transformation and school life is felt more effective than changing the curriculum by adding character education material in the curriculum content [9]. In relation to the development of school culture carried out in relation to self-development, the Ministry of National Education suggests through four things, which include: 1) Through routine activities; 2) Spontaneous activities; 3) Exemplary; and 4) Through conditioning [8]. The process is emphasized as a culture, so that students are able to make character education as a way of thinking, behaving, and behaving in schools and communities [3].

Education must pay attention to culture as a result of human creativity, taste, and will because culture encapsulates various sublime human works. For this reason, the need to mutually provide solutions through values that are in accordance with certain conditions of culture, tradition, religion and behaviour is a necessity. Therefore, school culture-based character education is one of the urgent school needs. For this reason, we need a concept in the form of a model for developing school culture to be more effective. Berkowitz reveals that "it makes sense that attempts to implement comprehensive school culture and pedagogical reform without adequate training is not likely to be overly successful" [4].

Effective character education is not by adding programs to school but rather a cultural transformation and school life as stated by Berkowitz that effective character education is not adding a program or set of programs to school. Rather it is a culture and life of the school. Furthermore, Berkowitz states "popular wisdom holds that the best way to implement character education is through a holistic approach that integrates development into every aspect of school life" [4]. Character development in every aspect of school life including through school culture. School culture can be learned from manifestations that appear in forms of behaviour and symbols of school characteristics.

In a study conducted by Ruyadi, it was concluded that character education based on local culture in schools had a positive impact on students, schools and communities, character education in schools would be effective if: (a) the character's basic values came from school culture, family and community; (b) integrated curricular and extracurricular programs to support character education; (c) school principals and teachers act as role models, substitutes for parents in schools, guardians, controllers, and control over students' ethical behaviour; (c) the implementation of character education is in the situation of the school's cultural environment [10].

The author considers the implementation of character education has not been carried out as a whole because character education is very important involving all school components, one of which is through school culture in accordance with local values and culture of the local community.

\section{METHOD}

This study was designed using the ADDIE model. ADDIE (Design, Development, Implementation, Evaluation). First, Analysis. At the analysis step, researchers conduct a needs assessment process and identify problems (needs) through interview methods, surveys and questionnaires in several elementary schools in Sinjai. The researcher conducted an interview with the principal / teacher and observation to obtain: (1) an overview of the implementation of character education; (2) description of school culture and supporting facilities for implementing school culture; (3) distribution of questionnaires, conducted to reveal the character of students. Data analysis was carried out by analysing qualitative and quantitative data. After getting an overview of the implementation of karate education, a description of the school culture, supporting facilities and facilities, and a description of the students' Character, the researcher then determined one school to conduct research and development models.

Second, Design. At the design step, the researcher made a blue print, a development of school culture-based karate education to improve the character of students. At this stage several things are done including: formulating the objectives to be achieved, determining implementation strategies, selecting methods, selecting media/ facilities/ infrastructure, determining the program \& implementation phase, determining evaluation tools, designing model books, designing and designing model devices: (1) Teacher's Guide book; (2) Student Guidebook, and design and design research instruments. The data collection technique used in the design stage is library research. The data analysis used is qualitative data analysis. The final stage of this process is to produce a prototype model in the form of a hypothetic model.

Third, Development. Stages carried out in the development of school culture-based karate education models, namely: expert validation assessment, model revision step, and step of socialization (simulation). Fourth, implementation and evaluation. At this stage, implementation was carried out to see the practicality of the model and the effectiveness of the model using the Pre-Experimental Designs of One-Shot Case Study trials [11]. For the final stage, an evaluation is carried out by distributing questionnaires for evaluating the character of students to get the results of improving the character of students. 


\section{RESULTS AND DISCUSSION}

\subsection{Results}

\subsubsection{Preliminary study analysis results}

At the analysis step, the number of schools that became the study population was 14 , with a sample of three teachers for each school and 15 students for each school. The school's environmental and cultural situation as a supporter of the implementation of karate education in elementary schools in Sinjai has not been fully fulfilled $(0.5 \leq 1.5)$. There are six schools that are still below average and need improvement, namely SDN No.103 Bonto Pare, SDN No. 06 Paruntu, SDN No 102 Lappa, SDN No 24 Biringere, SDN No 152 Cemmeng, and SDN No 07 Panreng. The types of characters classified as still low in the provision of facilities and school culture, namely: Religious, Honesty, Hard Work, Democracy, Curiosity, Care for the Circle, Social Care and Responsibility. For more details, see the following picture:

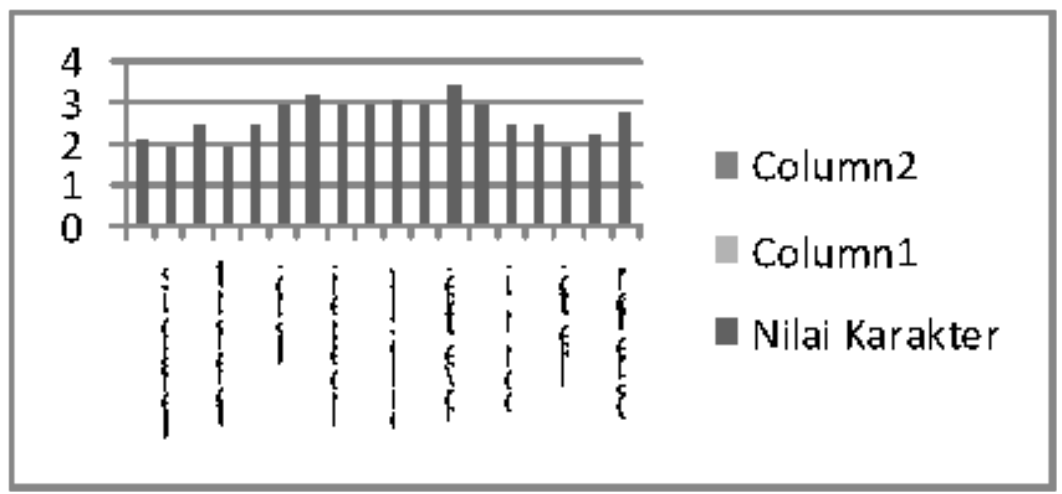

Figure 1 The value of character Participants of SD 07 Panreng

Many schools that have an implementation of character education that is not maximal, facilities and culture of supporting schools are inadequate, and the character of lowlevel students is determined by SD Negeri 07 Panreng as the object of research. The fundamental reason for choosing this school in addition to the three indicators above is that principals and teachers have a high willingness to implement a school culture-based character education model, and this school has characteristics that can represent schools in Sinjai because the school is located on the outskirts of County town. The number of teachers who became the object of research were 26 people and the number of students was 71 people for grades 4 - 5 .

\subsubsection{Validity of the Model}

The criteria used to decide that the school culture-based character education model has a degree of validity as explained in chapter three are (1) the total average value () for all minimal aspects in the category is quite valid; and (2) the value for each minimal aspect is in the valid category [12].

From the results of the validity test, it can be concluded that the character-based model of school culture, a set of models consisting of teacher manuals and student manuals, and research instruments all said to be valid, as summarized in the following table:

Table 1 Results of Validity of Model Books and Model Tools

\begin{tabular}{|c|c|c|c|c|c|c|c|c|}
\hline \multirow[b]{2}{*}{ No } & \multirow{2}{*}{$\begin{array}{c}\text { No Models \& Devices } \\
\text { Rated }\end{array}$} & \multicolumn{3}{|c|}{ Validator } & \multirow[b]{2}{*}{$\begin{array}{l}\text { Average } \\
\text { value }\end{array}$} & \multirow{2}{*}{$\begin{array}{l}\text { Score } \\
\mathbf{R}\end{array}$} & \multicolumn{2}{|c|}{ Decision } \\
\hline & & 1 & 2 & 3 & & & Valid & $\begin{array}{l}\text { Worth/ } \\
\text { Revision }\end{array}$ \\
\hline 1 & $\begin{array}{l}\text { Book of Characteristic } \\
\text { Education Model }\end{array}$ & 3.17 & 3.17 & 3.80 & 3.60 & 0.890 & $\begin{array}{l}\text { Very } \\
\text { Valid }\end{array}$ & $\begin{array}{l}\text { Worth } \\
\text { using }\end{array}$ \\
\hline 2 & Teacher's guidebook & 3.50 & 3.74 & 3.84 & 3.69 & 0.953 & $\begin{array}{l}\text { Very } \\
\text { Valid }\end{array}$ & $\begin{array}{l}\text { Worth } \\
\text { using }\end{array}$ \\
\hline 3 & Learner guidebook & 3.57 & 3.69 & 3.82 & 3.70 & 0.969 & $\begin{array}{l}\text { Very } \\
\text { Valid }\end{array}$ & $\begin{array}{l}\text { Worth } \\
\text { using }\end{array}$ \\
\hline
\end{tabular}


Table 2 Results of Validity of Research Instruments

\begin{tabular}{|c|c|c|c|c|c|c|c|c|}
\hline \multirow[b]{2}{*}{ No } & \multirow[b]{2}{*}{ Type of instrument assessed } & \multicolumn{3}{|c|}{ Validator } & \multirow{2}{*}{$\begin{array}{l}\text { Average } \\
\text { value }\end{array}$} & \multirow{2}{*}{$\begin{array}{l}\text { Score } \\
\mathbf{R}\end{array}$} & \multicolumn{2}{|c|}{ Decision } \\
\hline & & 1 & 2 & 3 & & & Valid & $\begin{array}{l}\text { Worth. } \\
\text { Revision }\end{array}$ \\
\hline 1 & $\begin{array}{l}\text { Questionnaire for practicality } \\
\text { model (teacher response) }\end{array}$ & 3.08 & 3.83 & 3.83 & 3.58 & 0.885 & $\begin{array}{l}\text { Very } \\
\text { Valid }\end{array}$ & Worth using \\
\hline 2 & $\begin{array}{l}\text { Sheets of model practical } \\
\text { observation instruments }\end{array}$ & 3.42 & 3.92 & 3.83 & 3.72 & 0.931 & $\begin{array}{l}\text { Very } \\
\text { Valid }\end{array}$ & Worth using \\
\hline 3 & $\begin{array}{l}\text { Questionnaire for the response } \\
\text { of students to the } \\
\text { effectiveness of the model }\end{array}$ & 3.19 & 3.96 & 3.81 & 3.65 & 0.906 & $\begin{array}{l}\text { Very } \\
\text { Valid }\end{array}$ & Worth using \\
\hline 4 & $\begin{array}{l}\text { Learners character assessment } \\
\text { sheet }\end{array}$ & 3.26 & 4.00 & 4.00 & 3.75 & 0.897 & $\begin{array}{l}\text { Very } \\
\text { Valid }\end{array}$ & Worth using \\
\hline
\end{tabular}

\subsubsection{Practicality of the model}

The practicality requirements of the school-based character education model can be seen from empirical theoretical data and data. The data are theoretically obtained if the validator's validation results are valid. Furthermore, it is stated empirically valid if it has been tested (implemented) in the field and meets the practicality criteria. to measure the practicality of the empirical model used two forms of research instruments that have met the validity criteria of the validator, namely: (1) the results of teacher response data analysis in applying the model, and (2) the results of model implementation data analysis.

Based on the results of the model implementation, it was found that the teacher's response to the implementation of the model for all aspects or components was in the "very good" category. While the results of the implementation of the model for all aspects or components were "fully implemented" and were in the "very good" category. Based on the results of the theoretical and empirical practicality tests as described above, it was concluded that the educational model of character based on school culture was stated to meet the criteria of practicality with very good categories.

\subsubsection{Model effectiveness}

The effectiveness of the model in terms of student responses at the evaluation stage shows that the majority of students respond positively. As many as $92 \%$ of students who respond positively and $8 \%$ of students who respond negatively. Thus, if viewed from the response of students the model has met the criteria of effectiveness in the category of "very effective".

If the effectiveness seen from the results of the character questionnaire of students at the evaluation stage shows that the character of the students is very high. A total of 71 respondents were assessed that none of them showed a low category. There are 5 types of character assessed, namely (1) honesty character with the category of "very high", (2) character honesty value in the category of "very high", (3) the value of character discipline in the category of "very high", (4) character value care for the environment in the category of "very high", and (5) social caring character values in the "high" category. Thus, if viewed from the results of the score of the students' character, then the model of character education based on school culture is effective. Based on the results of the two indicators of effectiveness above, it can be concluded that the model of culture-based karate education is effective.

\subsection{Discussion}

\subsubsection{Specific findings}

The specific findings of this study are: (1) there are still many elementary school teachers in Sinjai who do not know about the implementation of character education in a comprehensive manner. The implementation of character education according to them is only on integration in subjects, (2) Elementary schools in Sinjai do not yet have a specific and systematic strategy regarding the implementation of overall character education as the approach popularized by Lickona [7], [13], and Bandura [14], [3] evaluation of karate education in each elementary school has never been done routinely and thoroughly. The evaluation was only carried out through the learning process and did not use adequate instruments, (4) the provision of facilities, the creation of a conducive school environment and school culture had not been the priority of the school as a result of research stated by Berkowitz, Ruyadi, and Zuchdi, [15], [10], [16], [5] in the implementation of the karate education for all school members, school committees, principals, teachers, employees / staff, students must have a character education manual so that there are equal moral standards and are implemented together, (6) character guidebooks for teachers and students are responded to very positively by the school community.

\subsubsection{Model Specifications}

Book model, with specifications: (a) Rationality of school culture-based educational models that contain theoretical background and empirical importance of model development is carried out; (b) Theoretical foundation, contains theories about character education, character values, components of good character by Thomas Lickona [17], [13], theory Operant Conditioning B. F. Skinner (Walker), Gredler, Santrock, [17], [14], [18], moral development theory Jean Piaget (Michael), and Slavin, [19], 
[20], [21], moral development Lawrence Kohlberg (Slavin),; Manning, and Hook, [20], [21], [22], Bandura's theory of social-cognitive learning (Gredler) [14], and theories about school culture Zuchdi, Zamroni, Townsend, Schein, [16], [23], [24], [25], (c) Model Components. The stages of the model syntax are: (1) Moral Knowing, this activity is carried out during socialization, with details: conveying the background of the implementation, conveying the objectives clearly and operationally, conveying the benefits of the model clearly and operationally, and delivering the objectives to be achieved realistic and measurable; (2) Moral Feeling, The form of implementing this stage is: creating a conducive climate \& school environment, providing, advice and infrastructure facilities, involving various stakeholders and reflecting; (3) Moral Action, Form activities at this stage, namely: conditioning, spontaneous activities, exemplary and routine activities. In addition to the model syntax, there are other components, namely: Social System (Social System), Principles of Reaction (Principles of Reaction), Support Systems (Support System), and Impact Companion; (d) School culture-based character education models can only be used at the elementary school level; (e) The model of school culture based character education in its implementation requires understanding, commitment, and high willingness from all school members as stated by Supardi, Zuchdi, Zamroni, [25], [16], [22], that character can be implemented to the maximum if done consistently and with high commitment by all school members.

The teacher's guidebook has characteristics that contain the beliefs, values and commitments shared by all school members that become the school culture.

The student manual has its own characteristics because design and content describe the character of the local culture. The contents of the guidebook are accompanied by illustrations of pictures and folktales that depict the characters to be developed

\section{CONCLUSION}

The results of the preliminary study at the analysis stage revealed that the implementation of character education has not been implemented in a comprehensive manner, the fulfilment of the Environment and Culture Situation of the School of Character Education Implementation has not been fulfilled as a whole and the character of students in general has been categorized as low.

The School Culture-based character education model in Primary Schools was stated to meet the validity criteria, and practicality. Validated based on the results of the validity test by experts and practical because based on the results of the model implementation, it was found that the teacher's response to the implementation of the model for all aspects or components was in the "very good" category. While the results of the implementation of the model for all aspects or components are "fully implemented" or are in the "very good" category. The school culture-based character education model meets the effectiveness criteria. It is declared effective because it gets a positive response from students and can improve the character of students. The school culture-based character education model can be used to develop student character at the elementary school level

\section{ACKNOWLEDGMENT}

We are grateful this study was supported by the Institute of Research and Community Services (LP2M) of the Islamic Institute of Muhammadiyah Sinjai.

\section{REFERENCES}

[1] A. Baedowi, CalakEdu; educational essaysNo Title. Jakarta: Alvabet, 2012.

[2] A. Wibowo, Educational Malpractice. Yogyakarta: Genta Press, 2008.

[3] T. Asmaun S., and Angga, Character EducationBased Learning Design. Yogyakarta: Ar-Ruzz Media, 2012.

[4] M. W. Berkowitz, "What Works in Values Education," Int. J. Educ. Res., vol. 50, no. 3, pp. 153158, 2011.

[5] J. M. Asmani, Handbook for internalizing karater education in schools. Yogyakarta: Diva Press, 2011.

[6] A. Saefullah, "Institutions of Indonesia Fails to Build Character," NationKompas Daily, Jakarta, 2003.

[7] T. Lickona, Education for Character. New York: Bantam, 1991.

[8] C. for curriculum 2011 Ministry of National Education, Agency for research and development, Development Of National Cultural And Character Education School Guidelines. Jakarta: Center for Curriculum, 2011.

[9] F. Elkind, D.H. \& Sweet, "How to Do Character Education," Article Taken, 2009. [Online]. Available: http://www.wilderdom.com/Character.html.

[10] Y. Ruyadi, "Model Pendidikan Karakter Berbasis Kearifan Budaya Lokal," in Proceedings of The 4th International Conference on Teacher Education, 2010.

[11] Sugiyono, Educational Research Methods: Quantitative, Qualitative and $R \& D$ Approaches. Bandung: Alfabeta, 2008.

[12] Nurdin, "Model Pembelajaran Matematika yang Menumbuhkan Kemampuan Metakognitif untuk Menguasai Bahan Ajar," Universitas Negeri Surabaya, 2007. 
[19] Robert E. Slavin, Educational Psychology Theory and Practice. United States of America: Johns Hopkins University.

[20] S. A. Manning, Child And Adolescent Development. Washington, D.C: Departement of Psychology University of the District of Columbia, 1977.

[21] R. R. Hook, Forty Studies That Changed Psychology. New Jersey: Prentice Hall, 1999.

[22] Zamroni, The Dynamics of Quality Improvement. Yogyakarta: Gavin Kalam Utama, 2011.

[23] Townsend, T., Effective Schooling for the Communty. London and New York: Routledge, 1994.

[24] Schein. E.H., Organizational Culture and Leadership. Jossey-Bass, 2010.

[25] Supardi, Effective Schools, Basic Concepts \& Practices. Jakarta: Rajawali Press, 2013.

[18] Jhon W. Santrock, Life-Span Developmenet. USA: McGrow-Hill Company, Inc. 